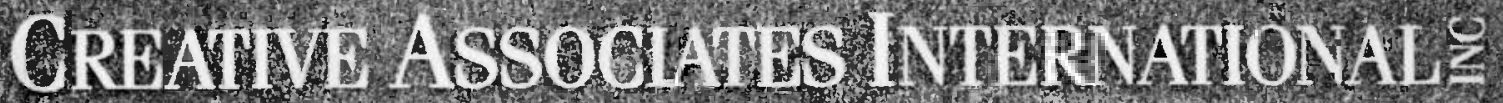

A FRAMEWORK FOR ACHIEVING GENDER EQUITY IN AFGHAN EDUCATION

POLICY ANALYSis and RECOMMENDATIONS 


\title{
A FRAMEWORK FOR ACHIEVING GENDER EQUITY IN AFGHAN EDUCATION
}

\section{POLICY ANALYSIS AND RECOMMENDATIONS}

\author{
Final Report
}

Prepared for:

UNITEd States AGenCy For INTERNational DEVFLopMENT O/AID/Rep Afghanistan

Prepared by:

Nagat El-Sanabary

Creative Associates InTERnational InC.

5301 Wisconsin Ave., N.W.

Suite 700

Washington, D.C. 20015

April 1993

Contract No. 306-0202-C-00-2034-00

In-House Project No. 564 


\section{CONTENTS}

Executive Summary

1. Background

1.1. The Special Situation of Post-War Afghanistan

1.2. The General Educational Situation

1.3 UNO/ESSP Support of Female Education

2. Gender Equity Issue No. 1.

The Access of Girls to Basic Primary Education

2.1 Disparities of Female Educational Access:

Quantitative Disparities

Qualitative Disparities

2.2 Constraints/Barriers to the Access of Afghan Girls to Education: Educational Constraints

Societal Constraints

2.3 Gender-Equity Principles and Objectives

2.4 Rationale

2.5 Resources for Increasing Access and Achieving Gender Equity

2.6 Strategies to Increase Access:

Increasing the Supply of School Places

Increasing the Demand for Girls' Education

2.7 Enrollment Targets and Indicators

2.8 Implementation

3. Gender Equity Issue No. 2.

Women Teachers: Their Availability and Quality

3.1 Female Teachers' Availability and Quality

3.2 Constraints on the Supply and Demand for Female Teachers 


\subsection{Gender Equity Objective}

\section{$3.4 \quad$ Rationale}

3.5 Resources for Increasing the Supply and Quality of Women Teachers

3.6 Policy Objectives

3.7 Policy Options

4. Gender Equity Issue No. 3.

The Quality of Girls' Education: Teaching Material

4.1 Objectives and Strategies

5. Increasing the Demand for Female Education

6. Adult Female Literacy

6.1 Rationale

6.2 Policy Objectives

6.3 Strategy to Enhance Female Literacy

6.4 Resources for Enhancing Female Literacy

7. Institutionalizing Gender Equity

8. The Need to Work Closely with Other Donors 


\section{Scope of Work}

This document was developed during a two-week visit by this consultant to Peshawar. During that period, she worked closely with the long-term advisors and the Afghan core group of educators within UNO/ESSP to formulate an equity policy that can be achieved within the Project's first three years and the anticipated extension of two years. The scope of work included the following:

1. Reviewing ESSP documentation on program level objectives.

2. Conducting interviews with long-term advisors and Afghan educators to discuss equity policy issues.

3. Formulating policies aiming at rendering ESSP more gender equitable, in preparation for an Afghan system of education that will seriously address gender disparities with the national educational system of Afghanistan.

4. Designing sets of criteria for the participation of schools in the technical assistance program offered by the ESSP in order to ensure that educational services are distributed equally among all different groups.

5. Designing a strategy that will facilitate the achievement of the policy within the life of the project. 


\section{Executive Summary}

Afghanistan has some of the lowest development indicators in the world: high maternal and infant mortality rates, low literacy rates particularly among females. Illiteracy rates are very high especially among Afghan women, estimated at 95 percent. This is a result of the extremely limited educational opportunities for girls especially in rural areas, despite the country's compulsory education law for females and males passed in 1919. The fourteen-year war between the communist regime and the Mujahedeen resistance forces destroyed the educational infrastructure, and deprived a whole generation of Afghan children of formal schooling. This generation lacks the necessary skills needed to rebuild this war-ravaged country. Most of the schools have been either destroyed or damaged, and are currently closed.

The Office of the AID Representative for Afghanistan, has provided basic educational assistance to the Afghans, through the Educational Sector Support Project (ESSP), since 1986. That assistance has been channelled through the Educational Center of Afghanistan (ACE), an organization set up by the ESSP as the Afghan counterpart Agency (ECA). Assistance to schools in Mujahedeen-controlled areas consisted mostly of provision of textbooks, teacher salaries, and some teacher training. The ESSP also supported a large number of refugee schools.

The O/AID/Rep's strategy for Afghanistan emphasizes education as a major factor in developing the human resources of the Afghan, and counteracting previous communist educational ideologies, and the new competing conservative Islamic trends. It emphasizes the role of women and women's education in empowering women and enabling them to contribute to their country's development, as participants and beneficiaries. Gender Equity is an important element of the Educational Sector Support Project.

This policy analysis is designed to assist UNO/ESSP to deliver educational services and resources to Afghan education in a gender equitable manner. Based on an analysis of the existing educational situation in Afghanistan and in the refugee communities in Pakistan, it strives to provide a means of understanding, formulating, and revising the educational policy of UNO/ESSP, and ultimately of the Ministry of Education in Afghanistan. It is an interactive process that begins with the production of this report and continues as various policy options are implemented, evaluated, revised and or institutionalized.

It provides the framework for evaluating educational options and alternative strategies and their anticipated impact. It also provides guidelines and targets to help ESSP enhance gender equity by increasing female educational access, achievement and persistence in Afghan education.

This policy analysis is part of an ongoing process that involves ESSP long-term management, Afghan male and female educators, community leaders, members of the Afghan counterpart agencies (ECAs)--consisting at the current time of the leadership of the Educational Center for Afghanistan (ECA), and ultimately officials of the Afghan central Ministry of Education (MOE) at the central, provincial, district and local levels. Only over a period of many years will educational disparities start to diminish. Because of the importance and complexity of 
the situation, the ESSP will plan an overall long-term approach to educational equity. At the same time, it will design activities that will respond to immediate needs and address the most pressing disparities. It focuses on four specific policy areas within the mandate of the ESSP:

1. The access and persistence of female students in primary education;

2. Female teacher training and deployment;

3. Curriculum Development and implementation; and

4. Functional literacy for adult Afghan women and young girls who did not have access to formal schooling.

This report is based on a two week-consultant trip to Peshawar, in January 1993 where I interviewed key staff members of the University of Nebraska at Omaha (UNO), the main contractor for the Education Sector Support Project. I also interviewed various Afghan men and women educators, specifically, the members of the Educational Center for Afghanistan, Afghan women participants in the Master Teacher Trainer (MTT) and the Teacher Trainer (TT) Programs. I visited classes, reviewed documents, and visited a number of Afghan and expatriate organizations involved in educational assistance.

A major constraint on this analysis, in addition to that of time, is the lack of up-to-date gender desegregated data on Afghan education, and lack of information generally on the Ministry of Education schools inside the country. As this material becomes available, with the ongoing efforts of the ESSP, it will be possible to refine the analysis, and estimate targets and objectively verifiable indicators of project impact.

The report is divided into eight parts. The first provides background information. Part two deals with the issue of girls' access to basic primary education. Part three deals with the issue of the supply and demand for teachers. Part four addresses the question of educational quality, with special focus on curriculum material and methods. Part five discusses ways of increasing the demand for girls' education. Part six deals with adult female literacy and related issues. Parts seven and eight are brief. The earlier deals with institutionalizing gender equity, and the latter stresses the importance of coordination and collaboration among donor agencies providing educational assistance.

\section{Background}

The situation of Afghanistan is unique, so is its educational assistance. The country has been devastated by a fourteen-year war between the communists and the Mujahedeen resistance forces. Since the overthrow of the communist regime in April 1992 and the founding of an Islamic government, the fighting continues and security remains a major problem. During that protracted year, the country's physical and human infrastructures have been destroyed and remain in need of major rehabilitation and reconstruction.

Currently, the country is going through a period of transition from one political ideology to another. The communist regime has been replaced by an Islamic government intent on 
promoting traditional Islamic values especially with regard to women and their position and role in society.

The country is in a state of flux. Hundreds of thousands of refugees from Pakistan and Iran have returned to their towns and villages, with very little resources, to start all over again, building their homes and communities. At the same time, thousand others are crossing the borders into Pakistan fleeing the fighting.

Before the war, Afghanistan had some of the lowest development indicators in the world: high maternal and infant mortality rates, low literacy rates, and a very low Gross National Product per capita (GNP). The war has aggravated the situation.

Specifically, educational indicators for Afghanistan have been extremely low: low literacy rates and enrollment ratios especially among the females. This is despite the country's compulsory education law for females and males passed in 1919.

Major disparities existed between enrollment in rural and urban areas, as shown in table 1. The data show major disadvantages for girls living in rural areas. Not only are the total percentages lower overall in rural areas, but they drop significantly among the older age groups. This is a result of the limited educational opportunities for girls in rural areas, especially beyond the primary grades, and that rural girls drop-out of school at an early age. This means that the ESSP will have to intensify its educational efforts designed to abridge the rural urban gap. 
Table 1

Female Population and School Enrollment by Age and Sex and Percentage to the Relative Age Group

Afghanistan, 1979 (Latest Available)

Urban Areas

Rural Areas

Number\% Enrolled*

Number\% Enrolled

Population Ages

$5-24$ years

390,770

$2,451,417$

Enrollment

$\begin{array}{lllll}\text { All Ages } & 86,927 & 22.3 & 103,581 & 4.2 \\ 5-9 \text { years } & 31,278 & 22.7 & 64,598 & 8.2 \\ 10-14 & 34,889 & 30.9 & 31,613 & 4.8 \\ 15-19 & 18,077 & 22.1 & 6,965 & 1.3 \\ 20-24 & 2,683 & 4.8 & 405 & 0.1\end{array}$

* Percent enrolled to the relative age group, or Gross Enrollment Ratio

Source: U.S. Bureau of the Census. 
During the war and the current impasse, a whole generation of Afghan children, female and male, have lost their chance to receive formal schooling, or non-formal education through apprenticeship and other traditional means of knowledge transfer. This generation lacks the necessary skills needed to rebuild this war-ravaged country. Most of the schools have been either destroyed or damaged, and are currently closed. The ones that remain open are often disrupted because of the fighting, most lack basic facilities, educational materials and teachers. Eye witness accounts report schools without walls, roofs, windows, doors, water, sanitary facilities, etc.

Rebuilding the educational system of Afghanistan is a major undertaken that requires a political commitment, long-term planning and extensive resources. American assistance can only help in the process, and must be coordinated with educational efforts of the national government,

other donors, and grass-roots organizations. The following population estimates and projections provide a rough assessment of the educational effort in the $1990 \mathrm{~s}$.

Table 2

\section{Children of Primary School Age in Afghanistan* Ages 5-14 years}

\begin{tabular}{llll} 
Year & Total & Males & Females \\
\hline 1990 & $4,638,000$ & $2,368,000$ & $2,270,000$ \\
1995 & $5,665,000$ & $2,886,000$ & $2,780,000$ \\
2000 & $7,713,000$ & $3,930,000$ & $3,783,000$ \\
& & \\
* Figures are rounded to the closest one thousand.
\end{tabular}

Source: Based on data obtained from US Bureau of the Census, International Data Base. 


\section{ESSP Support of Female Education}

The UNO/ESSP has been providing basic educational assistance since 1986. That assistance is channelled through the Educational Center of Afghanistan (ECA), an organization set up by the Educational Sector Support Project, as the Afghan counterpart Agency (ECA). Lack of a bilateral agreement between the U.S. Government and the Ministry of Education in Afghanistan complicates matters and calls for innovative approaches to educational support and
development.

The fact that the Educational Support Project is a cross-border operation creates various logistical problems in terms of delivery of services and supplies--teacher training and teacher salaries, and textbook distribution. The difficulties in monitoring and evaluation are substantial. Statistics on the number and location of schools, numbers of students and teachers are not readily available, and those existing are often unreliable. This makes it difficult to plan for educational reforms in general and gender equity in particular.

In January 1993, ESSP support for female education inside Afghanistan and in the refugee communities in Pakistan included the following:

Girls’ Primary Schools.

As of January 1993, ESSP has been supporting 70 girls' schools with a total enrollment of 7,279. Of these, 48 schools with a total enrollment of 4,251 were in 12 provinces inside Afghanistan, and 22 with an enrollment of 3,028 were in the refugee Communities in Pakistan. An additional 7,767 girls were enrolled in coeducational schools.

Master Teacher Trainer (MTT) and Teacher Trainer (TT) Programs.

Adult Female Literacy.

A special adult female literacy book has been developed and is being printed for use in female adult literacy classes.

Provision of Textbooks and Support Educational Materials.

ESSP provides textbooks and support materials to educational programs which target females.

Employment of approximately 50 Afghan women are among the ESSP staff as professionals and office workers. 


\section{Gender Equity Issue No. 1}

\subsection{The Access and Persistence of Girls in Primary Education}

The access of Afghan girls to primary education is extremely linited. Of more than two million Afghan females aged 5-14, only a small fraction attend schools of any kind, inside Afghanistan or in the refugee communities in Pakistan. Significant disparities exist between boy's enrollment rates and girls' enrollment rates, especially in rural and remote areas, and in the refugee communities in Pakistan. Furthermore, females are more likely than males to drop out of schools before gaining basic literacy and numeric skills. The disparities for Afghan girls are both quantitative and qualitative.

\section{Quantitative Disparities:}

In January 1993, ESSP was supporting 70 girls' schools with a total enrollment of 7,279 including: 48 schools enrolling 4,251 in 12 provinces inside Afghanistan, and 22 with an enrollment of 3,028 in the refugee communities in Pakistan. Females were only 2.13 percent of all students in the ESSP-supported schools inside Afghanistan (See Table 3).

Of the approximately one million children (according to UN estimates) of primary school age in the refugee communities in Pakistan and Iran, only a few thousand girls have had access to formal schooling. A UNHCR report issued in Peshawar (January 5, 1992) indicated that there were 70 primary schools and three middle UNHCR-supported schools for female refugee children in Pakistan in the NWFP. In 1991, 8,000 girls were enrolled in these schools, as compared 112,000 boys in schools for males. About 16 percent of all refugee children of primary school were enrolled in UNHCR-funded schools, including only 1.5 percent of the females .

A few thousand more girls were enrolled in schools supported by the various political parties, the International Rescue Committee (IRC), with support from the O/AID/Rep, and

several Afghan NGO's such as the Muslim Sisters's Organization of Afghanistan (MSOA). The IRC's female education program supported several hundred girls in refugee camp primary and secondary schools. The MSOA reported, in 1991, having 15,500 female students in primary and secondary schools inside Afghanistan, Pakistan, and Iran.

No up-to-date statistics are available on female or male enrollment in the Ministry of Education schools inside Afghanistan. 
Table 3

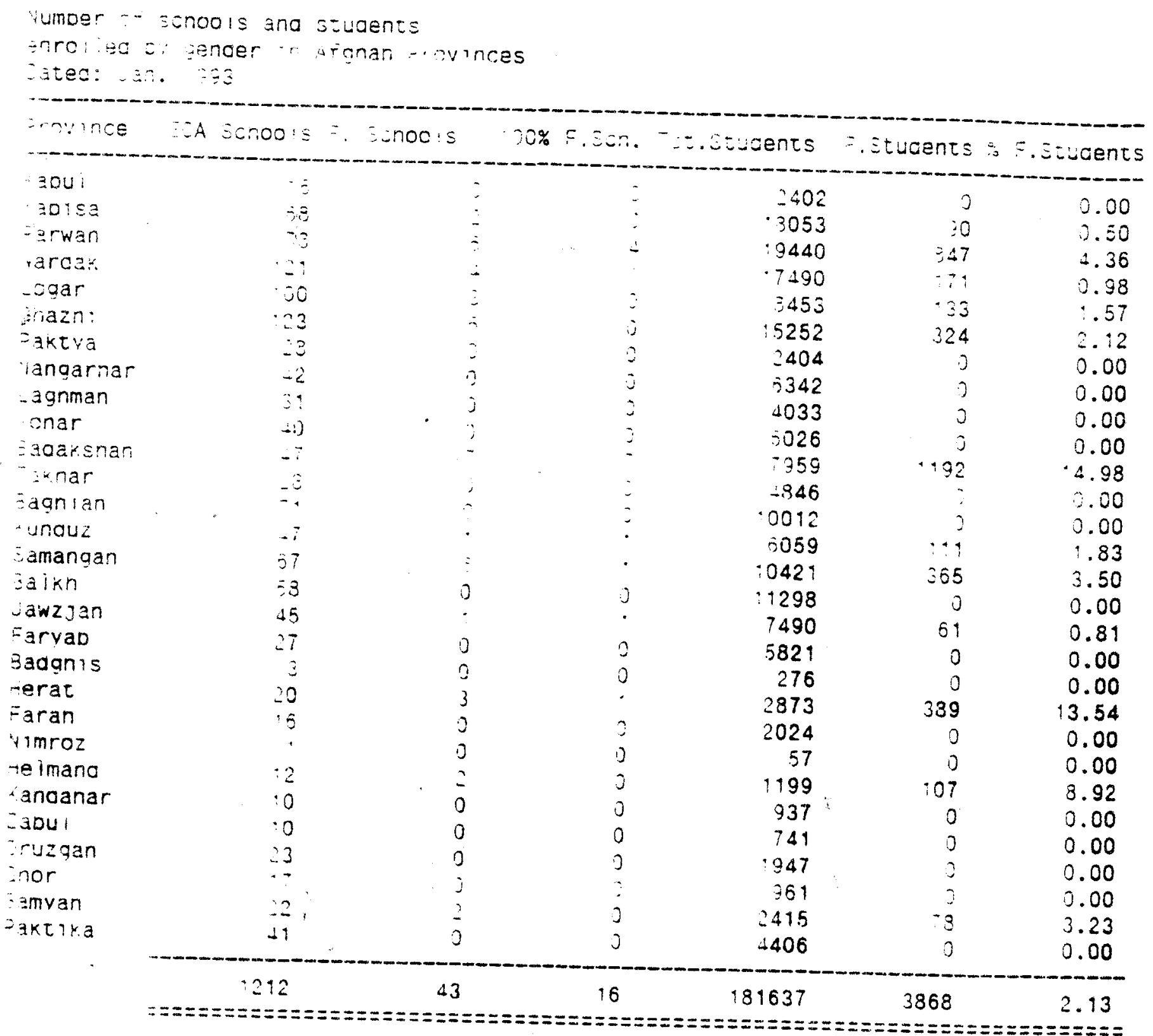

Jurce: LNO/ESSP/Pesnawar

- ropared $=\because$ : lagat Ei-Sanabary and Ruknsana Zeb 


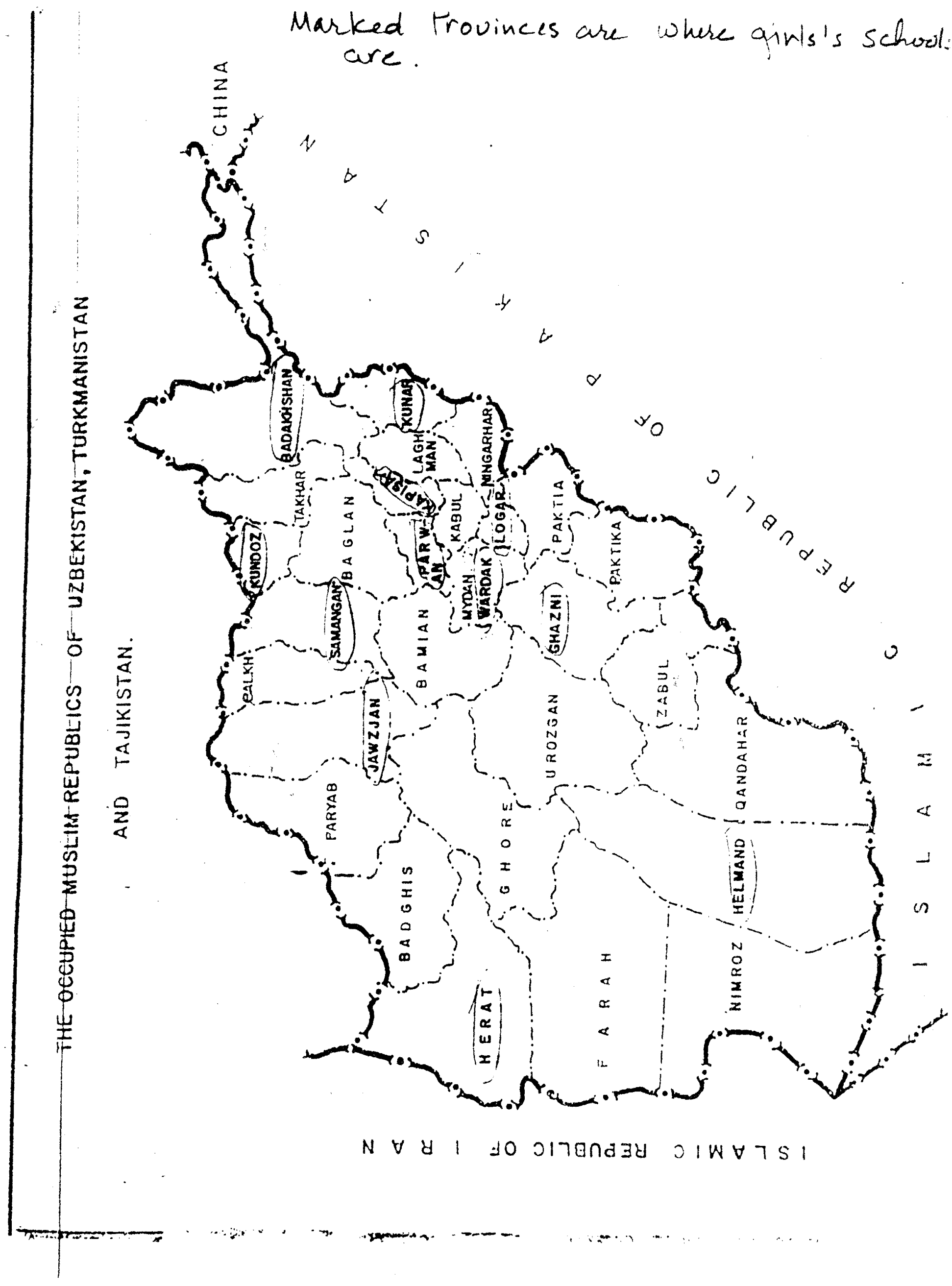




\section{Qualitative Disparities:}

The quality of education provided to Afghan children varies considerably depending on who runs the schools, their location, their resources, etc. No standards exist to determine what kind of education students receive, how they are taught, or what impact education has on their lives. Schools which may range from a few students and one teacher in a room in a house, a tent, an open space next to a tree, to a proper school of a few hundred students in a rented or government building. Most teachers are unqualified, and educational materials are scarce.

\subsection{Constraints/Barriers to Girls' Educational Access and Persistence}

The constraints on female access to education are both educational and socio-economic. They include the following:

\section{Educational Constraints:}

Lack of Physical, Human, and Material Resources.

- Lack of schools is a major obstacles to educational development in Afghanistan. The country's educational infrastructure has been destroyed by the war. Hardly any school in the country has escaped the devastation. All these schools need rehabilitation.

Additionally, the number of existing schools is too small to accommodate school age children in need of basic education, estimated at over four and half million males and females.

- Lack of Human Resources: qualified women teachers and administrators.

- Lack of reliable data on schools, teachers, or students either inside Afghanistan or in the shifting refugee communities in Pakistan and Iran.

\section{Societal Constraints:}

- Lack of appreciation of the value of female education among illiterate Afghan and a misconception that girls' education is counter to Islamic teachings.

- The undermining of people's confidence in education as a result of communist policy of indoctrination in communist ideology and undermining the indigenous culture. As one Afghan scholar, S.M. Yusuf Elmi, explained, during communist rule, "the pro-Moscow regime in Kabul, Soviet educational and administrative advisers have poured into the capital and tried their utmost to alter the traditional 
ways of our people and to sovietize the educational and cultural aspects of Afghan life." Thousands of young school girls were sent to Moscow for education and training with heavy emphasis on communist ideology.

- The inability of poor families to incur the direct and indirect cost of their children's education. In the case of girls, we may consider a) the direct cost of school supplies, uniforms and related expenses, b) the opportunity cost of schooling where girls are needed for domestic tasks or the care of siblings; and c) a cultural cost, i.e. the potential stigma that parents may have to suffer in supra conservative communities, for sending their daughters to school. In poor families, education and literacy are not a priority for people struggling for survival.

- Lack of security because of the continuing state of war, strife and factionalism.

- Excessive concern, among all organizations involved in educational assistance, over the perceived sensitivity of female education and training, and the hesitancy
to "expand too fast."

- Dwindling financial resources and the potential reduction of assistance from the US and other donors.

\subsection{Gender-Equity Principles and Objectives}

The ESSP is committed to the principle of equity for all children regardless of their gender, economic background, ethnic origin, or language. For the three-year duration of the ESSP, UNO, with the assistance of Creative Associates International, Inc., will adopt a gender equity policy and implement various interventions designed to reduce gender disparities and enhance female educational access and persistence. Project staff will give particular attention to reducing disparities for economically and ethnically disadvantaged girls, and those living in rural

The project will adopt interventions and strategies that have worked in other developing countries, especially Islamic ones. Yet, it will always be mindful of the unique situation of Afghanistan during the difficult years of rehabilitation and reconstruction.

The ESSP objectives for the three-year duration of the project are:

- $\quad$ Expanding girls' access to education;

- Improving girls' success and retention rates in school;

- Improving educational quality and curriculum relevance;

- Expanding the supply of women teachers and administrators. 
ways of our people and to sovietize the educational and cultural aspects of Afghan life." Thousands of young school girls were sent to Moscow for education and training with heavy emphasis on communist ideology.

- The inability of poor families to incur the direct and indirect cost of their children's education. In the case of girls, we may consider a) the direct cost of school supplies, uniforms and related expenses, b) the opportunity cost of schooling where girls are needed for domestic tasks or the care of siblings; and c) a cultural cost, i.e. the potential stigma that parents may have to suffer in supra conservative communities, for sending their daughters to school. In poor families, education and literacy are not a priority for people struggling for survival.

- Lack of security because of the continuing state of war, strife and factionalism.

- Excessive concern, among all organizations involved in educational assistance, over the perceived sensitivity of female education and training, and the hesitancy
to "expand too fast." Dwindling financial resources and the potential reduction of assistance from the
US and other donors.

\subsection{Gender-Equity Principles and Objectives}

The ESSP is committed to the principle of equity for all children regardless of their gender, economic background, ethnic origin, or language. For the three-year duration of the ESSP, UNO, with the assistance of Creative Associates International, Inc., will adopt a gender equity policy and implement various interventions designed to reduce gender disparities and enhance female educational access and persistence. Project staff will give particular attention to reducing disparities for economically and ethnically disadvantaged girls, and those living in rural

The project will adopt interventions and strategies that have worked in other developing countries, especially Islamic ones. Yet, it will always be mindful of the unique situation of Afghanistan during the difficult years of rehabilitation and reconstruction.

The ESSP objectives for the three-year duration of the project are:

- Expanding girls' access to education;

- Improving girls' success and retention rates in school;

- Improving educational quality and curriculum relevance;

- Expanding the supply of women teachers and administrators. 


\subsection{Rationale : Why Enhance Female Access to and persistence in Education?}

The guiding principles and rationale for ESSP's emphasis on girls' education are:

- Focus on gender equity emanates from the O/AID/Rep's policy for Afghanistan which emphasizes that "women's input into rebuilding Afghanistan will be essential to the growth of national prosperity, for the contribution that women make is a proven fact... In order for the development equation in Afghanistan to be changed and for real progress to be made, women and girls must, and can, be dynamic participants." (Afghanistan Strategy, March 1993)

- Research has shown that the education of women, the mothers of future generations, has various tangible effects upon important development goals such as: improved children's health, better performance in schools, and the general welfare of children, families and wider society.

- Women's education may be the best means of improving the health indicators for Afghanistan, by reducing maternal, infant mortality and fertility rates.

- Expanding the educational opportunities for girls and women will help improve the educational and economic standards of the Afghan people.

- Education provides women with basic skills to earn a living and contribute to family production and earning, since women are more likely than men to use their income to improve the conditions of their children and families.

- The fourteen-year war and its aftermath, has created a demographic imbalance whereby Afghan females are a majority of the population, estimated at between 60 and 75 percent. Consequently, women will have to carry a disproportionate share in rebuilding their country. Basic education for school-age girls, and functional literacy for teenage and adult females are therefore necessary to equip Afghan females with basic skills for their current and future roles in the home and community.

\subsection{Resources for Increasing Girls' Access to Basic Primary Education}

Despite the problems and constraints, several existing resources can be mobilizing in support of a more aggressive approach by the ESSP to enhance female gender equity.

- Interview data indicate the existence of a large unmet community demand for female education. The Afghans who remained in the country and those who lived in the refugee communities in Pakistan and Iran have come to appreciate the value of schooling for girls. In many instances, educated women were able to get jobs and support whole families while men were either fighting in the fields, disabled, 
or unemployed.

- UNO/ESSP has an excellent network of Afghan educators able and willing to advocate girls' education in their communities.

- The ongoing dialogue between the Educational Center for Afghanistan (ECA) and the Afghan Ministry of Education (MOE) should facilitate the collaboration needed for educational development generally, and gender equity in particular.

- Several Afghan provinces are now accessible and receptive to various kinds of education and training for Afghan females. Efforts were already underway in Jalalabad in the Nangarhar Province in early 1993.

- Basic education, health and women in development are strategic objective of the O/AID/Rep. This political commitment on the part of the mission, if matched by a commitment by the new Afghan government, could provide the needed impetus to further the cause of girls' education.

\subsection{Strategies to Increase Girls' Access to Primary Education}

To overcome existing constraints, and mobilize existing resources to enhance girls' access to primary education, the Educational Sector Support Project, in cooperation with the Afghan counterpart agencies, specifically the Educational Center for Afghanistan as the current both the supply and demand sides.

\section{On the Supply Side}

Increasing the Number of Schools and School Places. Following are alternatives

\section{Strategies}

- Support the rehabilitation and reopening of schools where both girls and boys are able to attend the primary grades together. UNO/ESSP should work with organizations involved in school rehabilitation and building programs such as UNICEF and the Norwegian Committee. The ESSP can provide teacher training and textbooks to rehabilitated or new schools.

- Increase female enrollment in the ESSP-supported schools where girls are currently enrolled. Currently only 2.13 percent of the students in ESSP-supported schools are females (See table 2)

- Increase the number of female schools receiving ESSP support. As of January 1993, only 43 girls' schools in 12 provinces were receiving ESSP support, as 
compared to 1,212 male schools in 28 provinces, or 3.5 all-female schools. ESSP should make sure there is at least one ESSP-supported school in each of the 29 Afghan provinces.

- Provide alternative schooling: non-graded one-room schools, and home schools (kala schools in the villages or Nahia schools in towns). These may be located in private homes or compounds, or attached to mosques which are available in every city, town or village. Provide these schools with materials and teacher training.

- Provide school facilities within a reasonable walking distance of residential areas. Smail schools with close ties to the community are effective in enhancing female access and persistence.

- Involve the local community in decisions regarding school locations, type, and support structures in order to encourage a sense of community ownership and involvement. Solicit the support of mullahs and local community leaders who may teach in the schools as well.

- Provide all-girls' schools or classes in communities opposed to mixed schooling. And Encourage mixed schooling in the primary grades, 1-3, where acceptable to the community.

- Encourage more efficient use of school buildings and facilities, where they exist, through double shifts.

\subsection{Targets and Indicators of Female Access to Primary Education}

Because of lack of base-line data, it is difficult to establish targets or objectively verifiable indicators (OVIs) to measure project success in achieving the gender-equity objective. As mentioned, no current reliable data exist on the number of schools, students, female student percentages, or gross enrollment ratios (percent of enrolled students to the relevant age group) Short- and long-term indicators of performance need to be set. Collection of baseline data is a prerequisite

The ESSP has already started collecting sex-desegregated data on schools, students, teachers, and administrators. As part of the ongoing school mapping effort, ESSP plans to identify current schools in each province and district, to keep records of all gender-segregated and coeducational schools and other educational facilities. Until this task is completed, the following are approximations.

\section{Student Indicators}

- The number of female students, per school, grade level, town, and province. 
- Girls as a percentage to total enrollment (as an indicator of gender disparities), per school, town and province.

- Gross enrollment ratios for females and males: i.e. the ratio of students enrolled to the eligible age group, desegregated by sex, and by province. This kind of information is necessary to identify and help reduce rural urban disparities.

\section{Targets}

Targets will be different between rural and urban areas because existing disparities.

\section{- Gross Enrollment Ratios}

Increasing the number of girls enrolled in schools as a percentage of the relative group especially of those in the age group 7 to 14 years. ESSP has already gathered data on the number of children age by province, as shown in Table 4. When educational data is obtained, it will be possible to calculate current and targeted enrollment ratios. 
Table 4

Afghan Children aged - 14 and the Number of Schools By Province

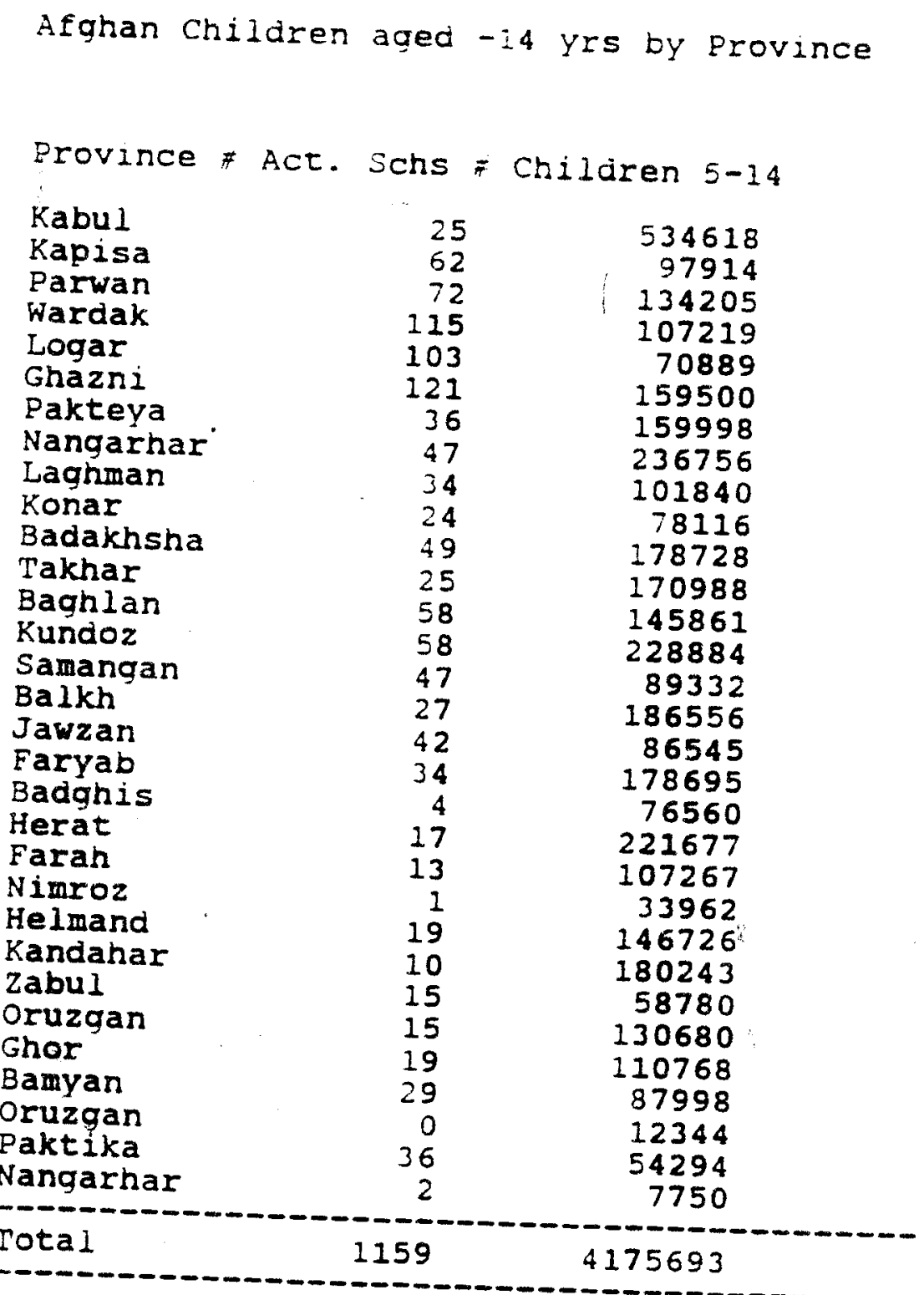

Source: ESSP Databas1993 
It is easier to work with this indicator. Increasing the percentage of female students to total enrollment per province can be easily calculated and actual rate of increase determined.

An ESSP statement that "Community Educational Development Councils (CEDCs) will ensure as a minimum community schools are comprised, in a configuration acceptable to the community, of at least 30 percent girls in classes $1-3$ and 25 percent in classes $4-6$, and 20 percent in higher grades as these schools are established."

Female percentage rates will be lower in rural than in urban schools. But these disparities must be closely monitored with a view to reducing them. An equitable distribution of educational facilities and enrollment between rural and urban areas will have to be an objective of long-term planning by the Afghan Ministry of education.

- The Number and Ratio of Female Schools Receiving ESSP Support:

A more attainable objective in the short run is to increase the number of all-girls or coeducational schools receiving ESSP support (curriculum materials, teacher salaries, and teacher training). A manageable objective is to have at least one such school in every Afghan province.

\subsection{Implementation}

- Begin implementation in towns that are geographically ăccessible and receptive to female education.

- Start a pilot project to implement the home school idea. Existing circumstance may necessitate starting the experiment among the refugees.

- Gather gender desegregated data on schools, students, and teachers.

- Conduct on-going monitoring and formative evaluation of various strategies/interventions to assess their effectiveness and impact.

- Make modifications based on evaluation/assessment data. 


\section{Gender Equity Issue No. 2}

Women Teachers: their Availability and Quality

\subsection{Background}

What is the existing supply of women teachers, their training level, and percentage of all teachers?

As with students, not much information is available on the numbers of women teachers, their percentage to all teachers, or their educational levels. The historically limited educational opportunities for Afghan women, the disruption caused by the war, and the limited educational and employment opportunities for Afghan women in the refugee communities have contributed to a low pool of educated Afghan women for teaching positions. No accurate data exist on the number of women teachers, their percentage of all teachers, or their training level either in ESSP. supported schools or in the MOE schools. This is because of a) The disruption caused by the war, b) general lack of information on MOE schools, and c) monitoring difficulties in ESSP/supported schools, and d) no effort was made previously to obtain gender-desegregated data on teachers.

The problem of women teachers supply is both quantitative and qualitative. Efforts must be expended simultaneously to increase the supply of women teachers, and raise their educational level.

\subsection{Constraints on the Supply and Demand for Women Teachers}

There are three major constraints on female teacher training:

- Shortage of educated Afghan women to meet the vast need for female teachers.

- Limited female mobility. Most educated Afghan women live in urban areas and ar not willing to teach in rural schools where the need for them is greatest.

- Inadequate teacher training facilities.

Cultural constraints including 1) attitudes towards women's work especially if it requires a woman to live away from her family; 2) preference in most communities that girls be taught by women teachers; and 3) the sensitivity of providing education and training for women especially by expatriate donor agencies 


\subsection{Gender-Equity Objective No 2: Increase the Number and Quality of Afghan Women Teachers}

Human Resources, specifically women teachers and administrators, are the backbone of female education. The ESSP will give priority to increasing the number of qualified Afghan women teachers especially in rural areas.

\subsection{Rationale}

- Having an adequate supply of women teachers is a necessary school input to increase girls access and persistence in basic education. This is especially true of Afghanistan and other traditional Islamic countries that prefer to have girls taught by women teachers.

- Teaching and learning can occur without a school but not without teachers to guide the students and facilitate their learning.

- Available research evidence from both economically advanced and developing countries indicates that women teachers provide important role models that promote female achievement and retention.

\subsection{Resources for Increasing the Supply and Quality of Women Teachers}

Despite Afghanistan's educational disadvantage, particularly with regards to females, the country has several thousand high school and college-educated women, many of whom with teacher training. Although their number is too small to meet the vast demand for women teachers, they are an important resource to be utilized.

There are already several teacher training facilities that can be utilized for pre-service and in-service teacher education. These include the teacher training institutes (dar-ul-muallimeen); the College of Education in Kabul University; the Academy of teacher Education; and the Faculty of Education in Jalalabad. Since ESSP is not involved in pre-service teacher training, it can provide these institutes with technical support and teaching materials.

ESSP and other expatriate and Afghan NGOs have been providing various types of Teacher and Master Teacher Training in the refugee communities. Yet the number of women teachers receiving such training has been very small. For instance, as of January 1993, 15 women have completed the Master Teacher Trainer Program (MTTP). Fourteen more women are currently receiving training: 7 school teachers, and 7 literacy teachers.

While the UNO/ESSP has moved much of its Master Teacher and Teacher trainer programs inside Afghanistan, the staff was still considering starting a women's program. During the summer of 1992, 539 men teachers participated in ESSP-run in-service teacher workshops in 9 provinces: Kunar, Nangarhar, Laghman, Paktya, Ghazni, Wardak, Kapisa, Helmand, and 
Ubzgdan. Requests were received for similar training of 200 women teachers in Jalalabad, but
had not been provided as of January 1993 .

\section{Policy Objectives}

- Increase the number of women in the Master Teacher Trainer (MTT) and Teacher Trainer (TT) Programs: train 40 women MTTs and 160 TTs per year.

- Increase the percentage of women receiving teacher training through short-term seminars and workshops. Provide such training to about 1000 women per year.

- Enhance female teachers capabilities.

- Design Teacher training workshops that are culturally appropriate : in towns and villages where the female teachers live.

- Provide incentives to trained teachers to encourage them to work where the need is greatest, especially in rural and remote geographic areas. Encourage the community to provide free or low-cost housing that are culturally acceptable.

\section{Policy Options}

The ESSP is firmly committed to increasing the number and qualifications of men and women teachers for Afghan education. It has several options to achieve this goal.

- Supporting a high-quality intensive teacher trainer and master teacher trainer
program;

Providing less intensive training aimed at combining quantitative growth as well
as qualitative enhancement.

- A combination of the two above approaches.

Although UNO/ESSP provides both intensive and short-term training, it emphasizes the first option in support of quality rather than quantity. This option has its merits, yet it falls short of meeting the vast quantitative needs of Afghan education. Under current circumstance, the proper mix between quality and quantity must be maintained.

UNO/ESSP staff in charge of teacher training have been moving very cautiously in their efforts to expand female teacher training. The question must be asked, however, to what extent can this level of training contribute to solving the serious shortage of women teachers? How many teachers need to have the level of subject matter and pedagogical training provided through the Master Teacher and teacher trainer Programs? What is the trickle-down effect of these 
trainers?

In recognition of the existing need, in January 1993, the ESSP was in the process of expanding teacher training for males and females in Peshawar, Quetta, and inside Afghanistan.

- A Women's Teacher Training Division, established in 1991, has provided training for Female Master trainers. Eleven MTTs have been trained, and 14 were receiving training in January 1993. These included 7 primary teachers and 7 literacy teachers.

- A similar Master Teacher Training Program was being set up in Quetta. The first group of five teachers were to receive training beginning in February 1993.

- A similar program was planned for the City of Jalalabad in the Nangarhar Province, which is only three hours away from Peshawar. A preliminary survey by the Director of the Peshawar MTT Program indicated a need for training of 150 women teachers. The community promised to provide residence for 5 Female Master Teacher Trainers from Peshawar, who will travel to Jalalabad to conduct a one-month seminar for school teachers.

- UNO/ESSP began establishing permanent teacher training sites inside Afghanistan. Priority consideration for training sites has been given to accessible provinces and towns where security is no problem such as Herat, Nimroz, Kandahar, Gardez, Jalalabad and possibly Wardak. Herat and Nimroz are open systems and would allow for joint training of males and females but logistically are more difficult to access, especially where expatriate advisors are involved in the training. (MTP Report, p. 14)

- $\quad$ ESSP should support the efforts of other Afghan and expatriate NGOs providing pre- and in-service teacher training by sharing expertise and resources. The task of training the needed women teachers is beyond the expertise and resources of any organization. Only through collaboration can they have an impact on such a serious problem.

\section{Gender Equity Issue No. 3: The Quality of Girls' Education: Teaching Materials}

There have been too many scattered efforts by numerous organizations to provide education for Afghan girls the efforts have often been of mediocre quality. Schools lack basic teaching materials, and use rote learning of curriculum materials that are irrelevant to the realities of women's lives. This is true of school as well as literacy materials. To improve the quality of girls' education, and that of boys' as well, the ESSP has a major role to play through its Curriculum Development Center. ESSP has been a leader in developing textbooks and teacher guides, silk screen charts, and other teaching aids. It has also developed student evaluation materials and has been on the cutting edge in introducing innovative teaching methods. 


\subsection{Objectives}

- Improve the quality of educational inputs, which will in turn have a positive impact on the enrollment and persistence of the children of the disadvantaged populations.

- Render the curriculum, textbooks, and other instructional materials more relevant to the roles of girls and women within the family. Produce textbooks and supplementary materials dealing with health, nutrition, farming, and incomegenerating skills for Afghan farm and poor women.

- Expand the supply and dissemination of textbooks, teacher manuals, and supplementary educational materials.

- Make schools more enjoyable experience by providing story books, games, and instructional aids.

- Design educational materials that girls and women can take home to discuss with other members of their families. These materials will deal with topics that are fully related to the daily lives of girls and women and their families. These materials will be simple, well illustrated and attractive.

Cultural sensitivity in the design of curriculum materials is of utmost importance. The experience of the Afghans under the communist regime has made them fearful that what is taught in school will undermine the family, traditional culture, and religion. The Muslims are not against women's education, but they want education that reinforces family values, and respects the culture and religion.

\section{Increasing the Demand for Female Education}

Although there is an unmet demand for female education inside Afghanistan and in the refugee communities, as indicated by the research conducted for this policy paper, and previous studies by this consultant, some communities suffer from a lack of demand for girls' education. Where the demand is low, because of poverty, lack of appreciation of the value of female education, lack of time because of girls' domestic responsibilities, efforts must be made to increase the demand for girls education.

Following are some strategies and interventions that have proven successful in traditional underdeveloped societies:

- Encourage community leaders to remind the communities that Islam is not against girls' education. It helps to repeat the saying of the Prophet Muhammad, which state: "the search for knowledge is the duty of every Muslim," "Seek knowledge from the cradle to the grave," and "Seek knowledge even if it be in China." 
- Support female NGOs involved in female education, formal and nonformal.

- As mentioned earlier, providing schools within walking distance increases the demand and facilitates female attendance and continuation in schools.

- Reducing the cost to parents:

a) Reduce direct cost by providing school uniforms, textbooks and supplies;

b) Reduce indirect/ opportunity cost by holding classes at times when the need for girls' labor in the home are minimal. Hold double shifts and seasonal classes.

c) Reduce the social cost by involving male and female community leaders in local educational councils or non-formal school community support groups.

- Provide school meals and health services: health record and vaccination;

- Although scholarships have been used in other developing countries to promote girls' education, they may not be feasible in the Afghan context because of limited resources. Non-monetary incentives may be an adequate substitute.

- Conduct culturally sensitive publicity campaigns.

\section{Adult Female Literacy}

\subsection{Rationale}

The illiteracy among Afghan women, estimated at 95 percent, is one of the highest in the world. The forced literacy campaign launched by the communist regime aroused antagonism among the Afghan who feared communist indoctrination, and the literacy classes conducted by the NGOs in the refugee camps in Pakistan and Afghanistan reached too few people to have a real impact. Furthermore, educational opportunities for young children inside Afghanistan and in the refugee communities in Pakistan and Iran were limited, thus perpetuating Afghanistan's backward educational situation. Consequently, the masses of Afghan women lack the necessary skills to earn a living and contribute to their families' well-being and the socio-economic development of their country.

Literacy has become an important development issue. Female literacy is now recognized as a key factor in socio-economic development. This is supported by research evidence documenting the positive effects of the mother's education on the nutrition as well as the physical, emotional and mental development of her children. Female literacy helps reduce infant and maternal mortality, as well as birth rates. Female education may, indeed, be the best 
investment in a country's future.

ESSP's involvement in literacy education began with the literacy classes provided to the Mujahideen during the war period. Additionally, the O/AID/Rep supported several adult literacy classes for Afghan women provided mainly by Afghan NGOs, and some Muslim and Western organizations. El-Sanabary (1992) identified several problems with the literacy programs for Afghan women in the refugee communities in Pakistan:

- The number of Afghan women who benefitted from these classes was too small to make a significant impact on the problem.

- The quality of literacy textbooks and other teaching material is uneven, and much of it is irrelevant to women's needs and concerns. Furthermore, there are no reading materials for the new literates. Once they conclude the course, most of the women will forget what they have learned because of lack of practice.

- Teaching methods were often inappropriate for adult learners.

- The duration of instruction, 4-to 6 months in most courses, is too short to ensure literacy acquisition.

- Literacy teachers did not receive adequate pre- or in-service training.

- Little communication existed among literacy teachers to share their successes and problems, or to learn from each others' experience.

\subsection{Policy Objective}

- To support literacy education for young girls and adult women in order to supplement basic primary education provided in school settings.

\subsection{Strategy to Enhance Female Literacy}

Because of its leadership and experiences in the areas of curriculum development and teacher training, the ESSP staff will not be involved in the provision of literacy education, but will adopt the following strategies to address the illiteracy problem:

- Provide technical support and instructional materials to other organizations involved in literacy activities.

- $\quad$ Produce culturally and gender-sensitive curriculum material for female literacy. This is particularly important because of the Afghan experience with literacy education during the communist regime where literacy and other educational materials were designed to undermine the family, religion, and indigenous culture. 
- Design educational materials that girls and women can take to discuss with other members of their families. These materials will deal with topics that are fully related to the daily lives of girls and women and their families. These materials will be simple, well illustrated and atractive.

- Train teacher trainers of literacy teachers, and provide training workshops for literacy teachers and curriculum developers.

- Support an innovative approach to literacy education, and promote new teaching methods.

Integrate literacy with health education and skills training.

Encourage and train graduates to use their education to teach other women and children. The home school idea, proposed by CAII before, should be tried among refugees in Pakistan and be continued inside Afghanistan later on. Promising graduates should be provided with materials -- teaching kits --, trained in their use, and helped to set up classes for small groups of women or children.

- $\quad$ Provide incentives to literacy teachers and learners.

- Introduce up-to-date, but culturally appropriate, techniques for training adult women. The use of slides and overhead charts, videos, silkscreens, distant learning through radio instruction, and other technology will be explored and pilot tested as warranted.

- Design refresher courses for literacy trainers who train women and other underserved populations. These courses will equip the trainers with new techniques that aim at further motivating adults in their pursuit of learning how to read and write.

- Promote community involvement in literacy education.

- Establish a "Task Force on Female Education and Literacy" consisting of literacy teachers and coordinators, experienced women teachers and administrators, and teacher trainers. The task force should meet regularly to share ideas and information, review and evaluate new literacy material, and plan and implement workshops on female literacy.

\subsection{Resources for Enhancing Female Literacy}

UNO and CAII will draw upon their wealth of experiences with literacy education and gender equity, and utilize the resources already available to them. UNO has already done the following: 
- A special adult female literacy book has been developed and is being printed for use in female adult literacy classes.

- An experienced literacy coordinator has been hired by UNO to oversee the literacy education.

- The Material Development Center has already started developing curriculum packets for home school use.

- ESSP has identified several expatriate and Afghan organizations already involved in various types of literacy and health education for Afghan women in Peshawar, Quetta, and inside Afghanistan including: the Afghan Women Resource center, the Afghan Women Education Center (in Islamabad), the Shuhada Clinic and School (in Quetta) the Swedish Committee, the Pak-German Group, the Danish Committee, the Australian Relief Committee, the Islamic Relief Agency (ISRA). ESSP's literacy education efforts will be coordinated with these groups whenever possible.

\section{Institutionalizing Gender Equity}

Setting up An Administrative Structure with Special Responsibility for Female Education

Achieving gender equity in Afghan education will require a political and social commitment from the central Ministry of Education and the local community. To ensure that commitment and to facilitate project monitoring and mobilization of community support, a special administrative structure must be set up and given responsibility for initiating programs, overall coordination of female education, and monitoring and evaluation.

\section{Stage 1. Prior to the Establishment of Bilateral Assistance}

Before bilateral assistance is established, it is very important for UNO staff to hire a qualified Afghan woman to coordinate the gender equity component. There are several Afghan women, in Peshawar, with excellent education and leadership skills who can work with community leaders to harness support for girls' education. One of these women should be recruited for this purpose.

UNO management has decided to appoint a task force on Female Education and literacy consisting of men and women from various Afghan communities to discuss issues, refine strategies, and coordinate efforts aimed at enhancing gender equity.

\section{Stage II: After Establishing Bilateral Assistance}

Once bilateral assistance has been established, UNO may support and provide technical assistance for an educational management system that include the following structure within the 
Ministry of Education. It suits the Afghan cultural traditions.

- A Deputy Minister in Charge of Female Education and Literacy. (This proposal was acceptable to ECA members in a meeting with this consultant to discuss issues of female education)

- A directorate of female education at the Provincial Level, This person should be a woman with an educational management background and school-site experience.

- A Directorate of Female Education at the district level.

These individuals, who should preferably be women, will insure the pursuit of gender equity, and oversee the necessary monitoring and evaluation of progress toward achieving project goals.

Additionally, in order to mobilize community support, and build upon the traditional community help tradition of the Afghan people, efforts must be made to involve community elders, male and female, in support of female education.

\section{The Need to Work Closely with Other Donors and Local Communities}

Gender equity is a long term goal that requires many human and physical resources. UNO/ESSP, EDC and CAII (contractors of this project) cannot pursue this goal in isolation from the work of other organizations. It requires collaboration with the various other donors, as well as with expatriate and Afghan NGOs who are also pursuing gender equity goals.

Any future Afghan government will not be able to afford full financial support for a comprehensive basic education system, even with assistance from international donors. Therefore, in order for the educational system developed under ESSP to extend to more than a fraction of the children of Afghanistan. Local communities will be encouraged to provide partial support for their schools. The main difficulty with this is the poverty of most local communities especially in rural areas. Most of the returning refugees are too poor to contribute financially to local education. But the 'support does not have to be financial. The Afghans have a tradition of local responsibility and initiative. Expectations of local support are not, therefore, unrealistic. Historically, Afghan communities formed elder's councils (Qaumee Jirgas) to deal with local affairs. These existing community institutions and structures can be mobilized to harness support for education in general, and girls' education in particular. Community elders and religious leaders, mullahs, can be prevailed upon to support girls' education. Mullahs can be recruited to teach younger girls in school rooms adjacent to local mosques. Provision of textbooks and teaching materials may be an adequate incentive to mobilize their support of girls' education. 